\title{
Phytochemical screening and in vitro antibacterial, antifungal, antioxidant and antitumor activities of the red propolis Alagoas
}

\author{
F. R. G. Silva ${ }^{a}$, T. M. S. Matias ${ }^{a}$, L. I. O. Souza ${ }^{a}$, T. J. Matos-Rocha ${ }^{a, b}$, \\ S. A. Fonseca ${ }^{a}$, K. C. Mousinho and A. F. Santos ${ }^{a, c *}$ \\ ${ }^{a}$ Centro Universitário Cesmac - CESMAC, Rua Cônego Machado, Farol, CEP 57051-160, Maceió, AL, Brasil \\ bUniversidade Estadual de Ciências da Saúde de Alagoas - UNCISAL, Av. Comendador Leão, Trapiche, \\ CEP 57025-000, Maceió, AL, Brasil \\ 'Universidade Estadual de Alagoas - UNEAL, Rua Governador Luiz Cavalcante, s/n, Alto Cruzeiro, \\ CEP 57300-005, Arapiraca, AL, Brasil \\ *e-mail: aldenirfeitosa@gmail.com
}

Received: July 20, 2017 - Accepted: December 27, 2017 - Distributed: August 31, 2019

(With 2 figures)

\begin{abstract}
The study aimed to evaluate the antimicrobial activity, antioxidant, toxicity and phytochemical screening of the Red Propolis Alagoas. Antimicrobial activity was evaluated by disk diffusion method. Determination of antioxidant activity was performed using the DPPH assay (1.1-diphenyl-2-picrylhydrazyl), FTC (ferric thiocyanate) and determination of phenolic compounds by Follin method. Toxicity was performed by the method of Artemia salina and cytotoxicity by MTT method. The phytochemical screening for the detection of allelochemicals was performed. The ethanol extract of propolis of Alagoas showed significant results for antimicrobial activity, and inhibitory activity for Staphylococcus aureus and Candida krusei. The antioxidant activity of the FTC method was $80 \%$ to $108.3 \%$ hydrogen peroxide kidnapping, the DPPH method showed an EC50 $3.97 \mathrm{mg} / \mathrm{mL}$, the content of total phenolic compounds was determined by calibration curve gallic acid, resulting from $0.0005 \mathrm{mg} / 100 \mathrm{~g}$ of gallic acid equivalent. The extract was non-toxic by $A$. salina method. The propolis extract showed high activity with a higher percentage than $75 \%$ inhibition of tumor cells OVCAR-8, SF-295 and HCT116. Chemical constituents were observed as flavonones, xanthones, flavonols, and Chalcones Auronas, Catechins and leucoanthocyanidins. It is concluded that the extract can be tested is considered a potential source of bioactive metabolites.
\end{abstract}

Keywords: antibacterial activity, anfungical activity, biological activity.

\section{Triagem fitoquimico e atividade antibacteriana, antifúngica, antioxidante e antitumoral in vitro da propólis vermelha de Alagoas}

\begin{abstract}
Resumo
O trabalho teve como objetivo avaliar a atividade antimicrobiana, antioxidante, a toxicidade e a prospecção fitoquímica da Própolis Vermelha de Alagoas. A atividade antimicrobiana foi avaliada pelo método de difusão em disco. A determinação do potencial antioxidante foi realizada utilizando o método de DPPH (1,1-difenil-2-picrilhidrazil), FTC (Tiocianato Férrico) e determinação de compostos fenólicos pelo método de Follin. A toxicidade foi realizada pelo método de Artemia salina e a citotoxicidade pelo método do MTT. Foi realizada a prospecção fitoquímica para a pesquisa de aleloquímicos. $\mathrm{O}$ extrato etanólico da própolis vermelha de Alagoas apresentou resultados significantes para atividade antimicrobiana, tendo a atividade inibitória para Staphylococcus aureus e Candida krusei. Quanto a atividade antioxidante o método de FTC teve $80 \%$ a $108,3 \%$ de sequestro de peróxido de hidrogênio, o método de DPPH apresentou um CE50 de 3,97 $\mu \mathrm{g} / \mathrm{mL}$, o teor de compostos fenólicos totais foi determinado mediante curva de calibração do ácido gálico, tendo resultado de $0,0005 \mathrm{mg} / 100 \mathrm{~g}$ equivalente de ácido gálico. O extrato foi atóxico pelo método de A. salina. O extrato da própolis mostrou elevada atividade com percentual de inibição maior que $75 \%$ sobre células tumorais OVCAR-8, SF-295 e HCT116. Foram observados constituintes químicos como flavononas, xantonas, flavonóis, Chalconas e Auronas, Catequinas e Leucoantocianidinas. Conclui-se que o extrato testado pode ser considerado é uma fonte potencial de metabólitos bioativos.
\end{abstract}

Palavras-chave: atividade antibacteriana, atividade antioxidante, atividade antitumoral. 


\section{Introduction}

The research of natural products with bioactive action has been carried out with the aim of discovering new substances that can be used in the treatment and prevention of Diseases (Costa, 2009). They are complex and aim the identification of useful active substances to be used in therapy, including antioxidant and antimicrobial molecules (Alves and Kubota, 2013).

Experience indicates that the selection of the species must have basement in popular medical indication, in isolation and determination of active substances and in the choice and implementation of pharmacological assays. The Brazil is a country with many natural resources of pharmacological action proven laboratory (Azevedo and Silva, 2006).

Among these products with popular usage, herbal action is propolis, which according to reports has anti-inflammatory, antimicrobial, antioxidant, healing, anesthesia, antitumor and recent studies are seeing their antiretroviral activity (Cabral, 2008). Red propolis is a resin collected by bees Apis mellifera from various parts of the plant Dalbergia ecastophyllum, its name derives from the Greek, and means in defense of the hive, because it is used by the bees as much of structural form as for Defense front of insects and micro-organisms (Cabral et al., 2009). The composition of propolis is complex, there are more than 180 identified compounds, deserving highlight the flavonoids, which are used as index of propolis samples qualification and possess antioxidant and antimicrobial (De-Melo et al., 2014). The chemical composition of substances present in propolis varies depending on the location and collection period. There are several products containing propolis, from food to cosmetics and pharmaceuticals semi-synthetic (Zunini et al., 2010).

The brazilian propolis is classified into 13 groups according to their composition and biological property, the best indicator of propolis is analysis of its chemical composition compared with the probable plant source, being the 13th type red propolis, demonstrating high biological activity, and has aroused a great interest in the international Market (Cabral, 2008). Propolis is predominantly red in some regions of the Northeast, mainly in the State of Alagoas, and is still little studied (Pinheiro, 2009).

Due to the absence of studies in Alagoas with information about Red propolis produced in the State, it is necessary to carry out studies on the bioactive potential of this natural product. Thus, the present work had as objective to evaluate the antimicrobial activity, antifungal, antioxidant, antitumor and toxicity of ethanolic extract of propolis red of Alagoas, in addition to the determination of their chemical composition.

\section{Material and Methods}

\subsection{Plant sample}

Red propolis of Alagoas was kindly provided by the beekeeper Ericsson Feitosa, being native to the northern coast of Alagoas and subjected to maceration in ethanol.

\subsection{Preparation of the extract}

The sample was weighed and macerated in ethanol at room temperature for 72 hours. The extract was filtered, evaporated in route-Rotary evaporator coupled to vacuum pump for removal of the solvent, so it was retrieved from the crude extract which has been stored and maintained under refrigeration.

\subsection{Antimicrobial activity test}

The evaluation of antimicrobial activity was performed as described in the literature methodology diffusion disk. Each isolated from Escherichia coli ATCC 25972, Staphylococcus aureus ATCC 25923, Pseudomonas aeruginosa ATCC 27853, Candida albicans ATCC 10231, Candida Krusei ATCC 6258, was first reactivated from stock cultures ATCC collection amid BHI liquid (Brain Heart Infusion) for $18-24$ h at $37{ }^{\circ} \mathrm{C}$, subsequently grown on Agar plates Mueller-Hintonpor 18-24 h, after growth and verified the presence of pure colonies has been prepared a suspension in saline solution equivalent to $0.5 \mathrm{McF}$ arland range, which corresponds to a concentration of approximately $0.1 \mathrm{~mL}$ x $10^{8} \mathrm{CFU} / \mathrm{mL}$.

Each bacterial suspension was evenly distributed with the aid of swabs in the surface of a Petri dish containing Agar Mueller Hinton for bacterial isolates and Sabouraud Agar for fungal isolates. Sterile paper records of approximately $6 \mathrm{~mm}$ in diameter were soaked with $20 \mu \mathrm{L}$ of the ethanolic extract solution sterile (the extract has been sterilized using milipore filter $0.22 \mathrm{~nm}$ ) at concentrations of $25 \mathrm{mg} / \mathrm{mL}$, $50 \mathrm{mg} / \mathrm{mL}, 75 \mathrm{mg} / \mathrm{mL}$ and $100 \mathrm{mg} / \mathrm{mL}$ and placed to dry on sterile environment. As standard strains were used: E. coli, S. aureus, P. aeruginosa, C. albicans and C. krusei.

As positive control of sensitivity has been used imipenem and fluconazole. And as negative control a disc containing $20 \mu \mathrm{L}$ of absolute ethanol (solvent used in the preparation of the extract). The disks containing the extract and the discs were inserted into the boards in controls that were inoculated micro-organisms (bacteria and fungi and standard tests) and were incubated for 24 hours in an oven at a temperature of about $37^{\circ} \mathrm{C}$. The tests were carried out in triplicate. After the end of the incubation, the plates have been analyzed as to the formation of growth inhibition halos and was considered antifungal or antibacterial activity when at least two plates it was possible to observe the presence of halos $8 \mathrm{~mm}$ or more.

\subsection{Qualitative analysis of antioxidant activity}

The extracts were analyzed by thin-layer chromatography (CCD) using default positive comparison routine. The plates were eluted with increasing polarity solvents and, after drying, were sprayed with $0.4 \mathrm{~mol} / \mathrm{L}$ solution of DPPH radical in $\mathrm{MeOH}$. The plates were observed until the appearance of yellow under purple coloring Fund, indicative of possible antioxidant activity.

\subsection{DPPH method (1.1-diphenyl-2-picrilhidrazil)}

The antioxidant potential of the ethanolic extract of propolis was determined by fotocolorimétrico in vitro method held through the kidnapping of free radicals, which 
was using the DPPH (1.1-diphenyl-2-picril-hidrazila). This analysis is based on ability that the antioxidant compounds have to donate a Proton to the DPPH forming stable resonance structures, stabilizing so called free radical (Alves and Kubota, 2013). The samples were diluted at concentrations of $500,125,50,10$ and $5 \mu \mathrm{g} / \mathrm{mL}$. For each concentration, the test was performed in triplicate. In $3 \mathrm{ml}$ of each sample were plus $0.1 \mathrm{~mL}$ of ethanolic solution of DPPH free radical, and incubated for 30 minutes at room temperature, away from light. White used the samples in each of the dilutions. Elapsed time reading the absorbâncias was held in $517 \mathrm{~nm}$ (spectrophotometer) of samples with DPPH against your specific white. How control was used a rate of $0.1 \mathrm{~mL}$ of ethanolic solution of DPPH added $3 \mathrm{ml}$ of ethanol. To evaluate the captadora of free radical activity, the percentage of inhibition was based on equation:\% inhibition $=[($ control absorbance-absorbance of sample $) /$ control absorbance] x 100.

\subsection{Calculation of $E C_{50}$}

The values of total antioxidant activity $\left(\mathrm{AAO}^{2}\right)$ and concentrations $\left(250,150,50,10\right.$ and $\left.5 \mu \mathrm{g} / \mathrm{mL}^{-1}\right)$ were related used the "Excel for Windows" program, obtaining, to extract the equation of the line. The resolution of this equation (replacing the Y-value per 50) resulted in the $\mathrm{EC}_{50}$ value, that is the concentration required to produce half $(50 \%)$ of maximum effect estimated at $100 \%$ for Red propolis extract.

\subsection{FTC method (Ferric Thiocyanate)}

The method FTC was done following the methodology described in the literature with minor modifications. The total antioxidant activity can be measured using the method FTC (Ferric Thiocyanate) where it was held at the $25 \mu \mathrm{g} / \mathrm{mL}$ concentrations, $50 \mu \mathrm{g} / \mathrm{mL}, 75 \mu \mathrm{g} / \mathrm{mL}$ and $100 \mu \mathrm{g} / \mathrm{mL}$. The FTC method was performed with the preparation of the substance in ethanol diluted in $6 \mathrm{ml}$ of distilled water to $1 \%$ ethanol. The taking of samples for storage, was held with extract, linoleic acid to $2.51 \%$ EtOH to $99 \%, 0.05 \mathrm{M}$ phosphate buffer and distilled $\mathrm{H} 2 \mathrm{O}$. Each sample was prepared in triplicate. The daily analysis solutions was held every 12:00 am, with a rate of $0.1 \mathrm{~mL}$ of the solution to storage and added to $5 \mathrm{~mL}$ $\mathrm{EtOH}$ to $75 \%, 0.1 \mathrm{~mL}(100 \mu \mathrm{L})$ of ammonium tiocionato to $30 \%$ and $0.1 \mathrm{~mL}(100 \mu \mathrm{L})$ of ferrous chloride $0.02 \mathrm{M}$ (Rodrigues et al., 2013).

To obtain the control solution hidroxibutilanisol (BHA) $0.01 \%$, was taken from a rate of $0,1 \mathrm{~mL}$ of control solution of BHA and added to $5 \mathrm{~mL}$ EtOH to $75 \%, 0.1 \mathrm{~mL}(100 \mu \mathrm{L})$ of ammonium thiocyanate to $30 \%$ and $0.1 \mathrm{~mL}(100 \mu \mathrm{L})$ of ferrous chloride $0.02 \mathrm{M}$. After 3 minutes at room temperature, the absorbance reading at $500 \mathrm{~nm}$. And the results were used to determine the percentage of inhibition on lipid oxidation by monitoring the amount of hydrogen peroxide at the beginning of the lipid peroxidation which led the formation of ferric thiocyanate, red substance.

\subsection{Determination of phenolic compounds}

The ethanolic extract obtained was used for the determination of the levels of total phenolics, by Spectrophotometric method using Folin-Ciocalteau reagent, according methodology described and the calibration curve constructed with Gallic acid standards ( 10 to $350 \mu \mathrm{g} / \mathrm{mL}$ ) and expressed as mg of EAG (Gallic acid equivalents) per $\mathrm{g}$ of extract (Amorim et al., 2013).

\subsection{Artemia salina toxicity}

The test was conducted in accordance with the procedure described in the literature. Each extract $(20 \mathrm{mg})$ was dissolved in $2 \mathrm{~mL}$ of appropriate solvent and this solution, 5 samples, 50 and $500 \mu \mathrm{L}$ were transferred, in triplicate, to the $5 \mathrm{~mL}$ vials. After total removal of the solvent, a saline solution $(0.38 \mathrm{~g} / \mathrm{L}, 5 \mathrm{~mL})$ was added in each of the bottles, resulting in final concentrations of 10,100 and $1000 \mu \mathrm{g} / \mathrm{mL}$, respectively. Larvae of $A$. salina nauplii type (10 per bottle) were added and after contact, 12:00 am the survivors were counted (Amorim et al., 2013).

\subsection{Antitumor activity}

Red propolis of Alagoas was evaluated as cytotoxic capacity front of 3 lineages of human tumor cells kept in culture, SF-295 (glioblastoma-human), OVCAR-8 (breast) and HCT-116 (colon) were provided by the National Cancer Institute (USA), having been grown in RPMI 1640, supplemented with $10 \%$ bovine fetal serum and $1 \%$ of antibiotics, kept in an oven at $37^{\circ} \mathrm{C}$ and containing 5\% $\mathrm{CO}_{2}$ atmosphere. The samples were diluted in sterile pure DMSO. The extracts were tested at a concentration of $50 \mu \mathrm{g} / \mathrm{mL}$. For determining the $\mathrm{CI}_{50}$, samples were tested in increasing concentrations in serial dilution. Analysis of cytotoxicity was made by MTT method, which has proved to be a fast, sensitive and to analyze the feasibility and the metabolic State of the cell, based on the conversion of salt-3 (4.5-dimethyl-2-thiazole ring)-2.5-diphenyl-tetrazolium bromide (MTT) to formazan, blue from mitochondrial enzymes (e.g. succinyl dehydrogenase) present only in metabolically active cells.

The cells were plated at a concentration of $0.1 \times 10^{6} \mathrm{cell} / \mathrm{mL}$ for SF-295 strains and 0.7 x OVCAR- 8 and $10^{5}$ cell $/ \mathrm{mL}$ for the HCT- 8 . The plates were incubated for 72 hours in an oven at $5 \% \mathrm{CO}_{2}$ at $37{ }^{\circ} \mathrm{C}$. At the end of this, they were centrifuged and supernatant, removed. Then we added $150 \mu \mathrm{L}$ MTT solution (tetrazolium salt), and the plates were incubated for 3:00. The absorbance was read after dissolution of the precipitate with $150 \mu \mathrm{L}$ of pure DMSO on board the $595 \mathrm{~nm}$ spectrophotometer. For interpretation of results of antitumor activity, an intensity scale was used to evaluate the cytotoxic potential of the samples tested. Samples of no activity (SA), with little activity (PA, inhibition of cell growth ranging from 1 to $50 \%$ ), with moderate activity (MO, inhibition of cell growth ranging from 50 to $75 \%$ ) and with a lot of activity (MA, growth inhibition ranging from 75 to $100 \%$ ). The experiments were analyzed according to the mean \pm standard deviation of the 
mean (DPM) of the percentage of cell growth inhibition using the program GraphPad Prism.

\subsection{Phytochemical analysis of the extract}

To perform the phytochemical screening stage was based on the methodology proposed by Matos (1997) which has been crafted with some adaptations in order to carry out prospecting the following allelochemicals: phenols, pyrogalic tannins, phlobaphene tannins, anthocyanin and anthocyanidin, flavones, flavonols, xanthones, chalcones, aurones, flavononois, leucoantocianidinas, catechins, flavonones, flavonols, xanthones, steroids and triterpenoids saponins.

Of each extract obtained and used in bioassays from $35 \mathrm{~mL}$ to the phytochemical prospecting, which have been split into seven portions of $3 \mathrm{~mL}$ test tubes numbered and identified according to each type of extract and one $10 \mathrm{~mL}$ portion in beakers labeled. Heated the beaker in a Bain-Marie by means of a hot plate with agitation until the total evaporation from the liquid, which was used in tests for steroids, and triterpenoid saponins.

\section{Results}

The extract analyzed by thin-layer chromatography (CCD), qualitative method of DPPH, showed antioxidant activity due to the presence of yellow spots on the purple background. In the quantitative method DPPH concentrations evaluated $500 \mu \mathrm{g} / \mathrm{mL}$ of ethanolic extract confirmed the presence of antioxidant activity (Graphic 1).

The concentration of $250 \mu \mathrm{g} / \mathrm{mL}$ was that promoted the highest percentage $(92.4 \%)$ of antioxidant activity in ethanolic extract of propolis, the concentration of $5 \mu \mathrm{g} / \mathrm{mL}$ promoted the lower potential $(22.1 \%)$ of antioxidant activity. Red propolis of Alagoas presented $\mathrm{EC}_{50}$ worth $3.97 \mu \mathrm{g} / \mathrm{mL}$ by the DPPH method. The $\mathrm{EC}_{50}$ value expresses the concentration that eliminates $50 \%$ of free radicals. The smaller this concentration, the greater the activity.

The capacity of the ethanolic extract of propolis Alagoas red kidnap hydrogen peroxide verified that test above $86 \%$ at concentrations of $5-100 \mu \mathrm{g} / \mathrm{mL}$ (Graphic 2).

The total content of phenolic compounds was determined by calibration curve of Gallic acid and in the present research was to $0.0005 \mu \mathrm{g} / \mathrm{mL}$ Gallic acid equivalents per gram of sample of ethanolic extract of propolis from Alagoas. In this research, were observed as chemical constituents of ethanolic extract of propolis of Alagoas: Red flavonones, xanthones, triterpenoids pentacíclicos free, flavonols, cinnamic derivatives, fenilpropanoglicosídeos, condensed anthocyanidins and leucoanthocyanidins.

The ethanolic extract of propolis showed no activity in front of gram-negative bacteria, but inhibitory activity in all presented at concentrations of $25-100 \mathrm{mg} / \mathrm{mL}$ for S. aureus, being $75 \mathrm{mg} / \mathrm{mL}$ concentration of greater sensitivity (Table 1), C. krusei $50 \mathrm{mg} / \mathrm{mL}$ was the concentration which was more halo size (Table 1), pointing to the importance of research to provide the search for new antibiotics Since many microorganisms exhibit resistance to some medications marketed.
According to the results, the Red propolis of Alagoas in the form of ethanolic extract was considered non-toxic front of $A$. salina in the concentrations tested $(200-1000 \mu \mathrm{g} / \mathrm{mL})$. The mortality rate of Artemia salina front red propolis of Alagoas: $1000 \mu \mathrm{g} / \mathrm{mL}(6.73 \%), 800 \mu \mathrm{g} / \mathrm{mL}(6.66 \%)$, $600 \mu \mathrm{g} / \mathrm{mL}(6.36 \%), 400 \mu \mathrm{g} / \mathrm{mL}(3.33 \%)$ and $200 \mu \mathrm{g} / \mathrm{mL}$ $(0.0 \%)$.

Cytotoxicity studies were performed by the method MTT in ovarian tumor cell lines (OVCAR-8), glioblastoma (SF-295) and human colon carcinoma (HCT116). Were considered with high activity samples with inhibition percentage greater than $75 \%$. As shown in Table 2, at

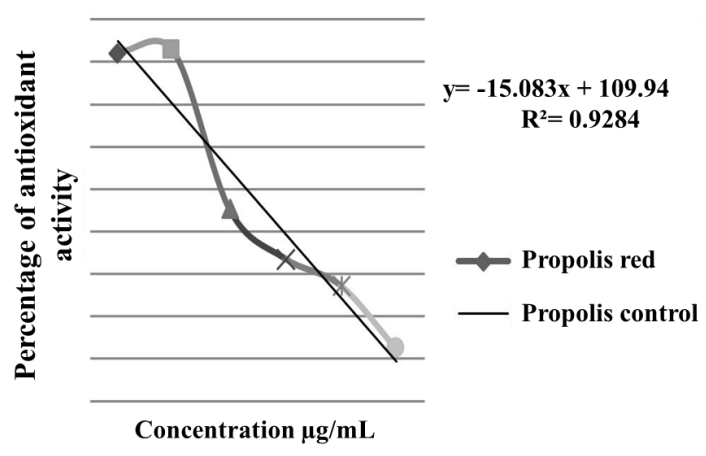

Graphic 1. Evaluation of antioxidant activity through the kidnapper of DPPH radical activity of propolis Alagoas red.

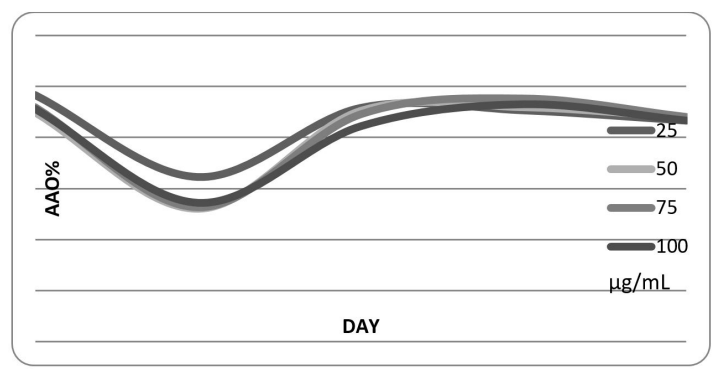

Graphic 2. Percentage of total antioxidant activity (AAO\%) obtained from Ferric Thiocyanate method (FTC) from Red Propolis of Alagoas.

Table 1. Anti-Staphylococcus aureus and Anti-Candida activities of ethanolic extract of propolis from Alagoas.

\begin{tabular}{ccc}
\hline \multicolumn{3}{c}{ Anti-Staphylococcus aureus activity } \\
\hline $\begin{array}{c}\text { Concentracion } \\
\mathbf{m g} / \mathbf{m L}\end{array}$ & $\begin{array}{c}\text { Halo in average } \\
\mathbf{m m}\end{array}$ & $\begin{array}{c}\text { Standard } \\
\text { Deviation }\end{array}$ \\
\hline 25 & 10.67 & 4.16 \\
50 & 13 & 1.73 \\
75 & 15.67 & 2.08 \\
100 & 13 & 1 \\
\hline \multicolumn{3}{c}{ Anti-Candida activity } \\
50 & 10.4 & 2.60 \\
75 & 12.4 & 0.89 \\
100 & 11.4 & 2.41 \\
\hline
\end{tabular}


Table 2. Percentage of inhibition of propolis red front of SF-295, OVCAR-8 and HCT-116.

\begin{tabular}{|c|c|c|c|c|c|c|}
\hline \multirow[b]{2}{*}{ FRACTIONS } & \multicolumn{2}{|l|}{ SF-295 } & \multicolumn{2}{|l|}{ HCT-116 } & \multicolumn{2}{|l|}{ OVCAR-8 } \\
\hline & $\begin{array}{c}\text { Average inhibition } \\
(\%)\end{array}$ & DP & $\begin{array}{c}\text { Average inhibition } \\
(\%)\end{array}$ & DP & $\begin{array}{c}\text { Average inhibition } \\
(\%)\end{array}$ & DP \\
\hline P. vermelha & 87.76 & 9.56 & 88.70 & 2.60 & 93.64 & 4.83 \\
\hline Gel C & - & - & 8.16 & 0.83 & 23.30 & 3.08 \\
\hline
\end{tabular}

SF-295 (glioblastoma-human); HCT-116 (colon); OVCAR-8 (breast).

Table 3. Evaluation of in vitro cytotoxicity of extracts by MTT method after 72 hours of incubation in front of 4 tumor lines. $\mathrm{CI}_{50}$ and $95 \%(\mu \mathrm{g} / \mathrm{mL})$ determined from average and its DPM performed in duplicate and determined by non-linear regression in the program GraphPad Prism, version 5.0.

\begin{tabular}{lcccc}
\hline \multirow{2}{*}{ FRACTIONS } & \multicolumn{4}{c}{$\mathbf{I C}_{\mathbf{5 0}}(\boldsymbol{\mu g} / \mathbf{m L})$} \\
\cline { 2 - 5 } & HCT-116 & HL-60 & SF-295 & OVCAR-8 \\
\hline PVM & $\sim 25.26$ & $13.53(10.14-18.05)$ & $34.27(24.28-48.37)$ & $28.76(24.42-33.87)$ \\
PV & $41.01(30.21-55.67)$ & $29.32(22.60-38.03)$ & $\geq 50 \mathrm{ug} / \mathrm{mL}$ & $\geq 50 \mathrm{ug} / \mathrm{mL}$ \\
Doxorubicin & $0.12(0.09-0.17)$ & $0.02(0.01-0.02)$ & $0.24(0.2-0.27)$ & $0.26(0.17-0.30)$ \\
\hline
\end{tabular}

$\mathrm{PVM}=$ Red propolis of Marechal Deodoro-AL; PV = Propolis vermelha controle; Human colon cancer cell line (HCT-116); promyelocytic leukemia (HL-60); SF-295 (glioblastoma-human); OVCAR-8 (breast); IC50 and $95 \%$ confidence interval - CI $(\mu \mathrm{g} / \mathrm{mL})$ calculated based on the mean and corresponding standard deviation of the mean and determined through non-linear regression.

OVCAR- 8 cells were more sensitive, SF-295 cells already the least sensitive. The cytotoxic activity of the samples is presented in Table 2, with their respective percentages of inhibition.

In Table 3 it is observed that during the in vitro cytotoxicity test the Red propolis extract were active as positive control, doxorubicin.

\section{Discussion}

The DPPH is a stable free radical which has been widely used to evaluate the antioxidant activity of extracts and pure substances. The effect of antioxidants on the DPPH is due to hydrogen donor capacity of these substances which are usually phenolic compounds (Souza, 2006).

The concentration of $250 \mu \mathrm{g} / \mathrm{mL}$ was that promoted the highest percentage (92.4\%) of antioxidant activity in ethanolic extract of propolis, the concentration of $5 \mu \mathrm{g} / \mathrm{mL}$ promoted the lower potential $(22.1 \%)$ of antioxidant activity. Red propolis of Alagoas presented $\mathrm{EC}_{50}$ worth $3.97 \mu \mathrm{g} / \mathrm{mL}$ by the $\mathrm{DPPH}$ method. The $\mathrm{EC}_{50}$ value expresses the concentration that eliminates $50 \%$ of free radicals. The smaller this concentration, the greater the activity.

These results were higher than those described by Bonamigo et al. (2017), that when assessing the ethanolic extract of propolis (collected from the state of Mato Grosso do Sul) obtained from the stingless bees Scaptotrigona depilis (EEP-S) and Melipona quadrifasciata anthidioides (EEP-M), which are found in Brazil, demonstrated antioxidant activity percentage of $60 \%$ inhibition at a concentration of $60,91 \mu \mathrm{g} / \mathrm{mL}$ for EEP-M and EEP-S demonstrated antioxidant activity percentage of $60 \%$ inhibition at a concentration of $300 \mu \mathrm{g} / \mathrm{mL}$.

Silva et al. (2017) demonstrated ethanolic extract of red propolis R01Et.B2 (lot number L02, red color,
Sergipe apiary, Brazil, resinous appearance) showed strong antioxidant activity of more than $95 \%$ at a concentration of $750 \mu \mathrm{g} . \mathrm{mL}^{-1}$ and R02.B2 (lot number L01, red color, Alagoas apiary, Brazil, resinous appearance) showed strong antioxidant activity of more than $80 \%$ at a concentration of $750 \mu \mathrm{g} \cdot \mathrm{mL}^{-1}$. All supercritical extracts of propolis also exhibited strong antioxidant activity (over $60 \%$ ) at that concentration, except for B03SC.B2, which had weak antioxidant activity.

Comparing the results of the present study to those obtained by Mendonça et al. (2015) and Silva et al. (2017), it is evident that in relation to the antioxidant activity, propolis samples collected in the same geographic region demonstrated similar properties, although they were collected at different periods. In addition, we conclude that red propolis samples had the highest overall antioxidant potential, and that the conventional method of extraction by ethanol produced extracts with stronger antioxidant activity.

The FTC is required for verification of pró-oxidantes substances that the DPPH method may not detect (Cabral et al., 2009). The quantity of peroxides in the early stages of lipid peroxidation was measured by the FTC method. Second Aqil et al. (2006) this peroxide produced in the lipid peroxidation, will react with peroxide to ferric chloride ferrous forming ions. The ferric ions then unite with ammonium thiocyanate and produces ferric thiocyanate, red substance and indicative of greater absorbance.

The total content of phenolic compounds was determined by calibration curve of Gallic acid and in the present research was to $0.0005 \mu \mathrm{g} / \mathrm{mL}$ Gallic acid equivalents per gram of sample of ethanolic extract of propolis of Alagoas.

As the ability of the extract of propolis kidnap hydrogen peroxide assessed by Ferric Thiocyanate method, similar to our findings were described by Rodrigues et al. (2013), which obtained average values for percentages of catches 
between $82.8 \%$ and $103.16 \%$, in this case, both the stem as the sheet showed good results of antioxidant activity for ethanolic extract of leaves and the stalk of S. obtusifolia.

According to Sousa et al. (2007) antioxidant activity related to phenolic compounds from their reducing properties and chemical structure of the same. The role played by them is important in the neutralization or the kidnapping of free radicals, beyond Chelation for transition metals, acting both in the initiation step as in the propagation of the oxidative process. The antioxidant action of propolis is attributed to its component flavonoids, among which we might mention quercetin, daidzein, apigenin and genistein (Kamiya et al., 2012). Quercetin and daidzein have been detected by Franchi Jr. et al. (2012) in Brazilian red propolis from Alagoas State. Others studies also detected antioxidant activity of the flavonoids isoliquiritigenin (Ondrias et al., 1997) and pinobanksin (Blanco-Ayala et al., 2013) in red propolis.

The phenolic compounds of plants fall into various categories, such as: simple phenolics, phenolic acids, coumarins, flavonoids, hydrolysable and condensed tannins, stilbenes, Lignans and lignins (Mensor et al., 2001). Propolis collected in Portugal, Silva et al. (2012) reported MIC values (in $\mu \mathrm{g} / \mathrm{mL}$ ) ranging from 590 to 1720 for S. aureus, 1560 to 2810 for $P$. aeruginosa and 3190 to 4860 for $E$. coli. Campos et al. (2014) found antimicrobial activity in an $80 \%$ ethanol extract of Brazilian stingless bees with MICs of $3100 \mu \mathrm{g} / \mathrm{mL}$ for $S$. aureus and C. albicans.

These results were higher than those described by Nina et al. (2015), that propolis from Romeral 4, Vilches, San Clemente 3 and 4 and San Javier 4 and 5 are active against the $S$. aureus microorganism with MICs in the range 62.5 to $125 \mu \mathrm{g} / \mathrm{mL}$. When considering the methicillin-resistant S. aureus, San Clemente 4 and San Javier 5 samples can be regarded as promising antibacterial agents with MICs of $62.5 \mu \mathrm{g} / \mathrm{mL}$.

A similar result was obtained by Silva et al. (2017) observed that red propolis showed the highest antimicrobial activity among the samples obtained by both ethanolic and supercritical extraction methods. R02Et.B2 sample (ethanolic red extract from Alagoas) exhibited the highest antimicrobial activity against Enterococcus sp., Staphylococcus aureus, and Klebsiella sp. with MIC values of $31.3,62.5$, and $31.3 \mu \mathrm{g} . \mathrm{mL}^{-1}$.Observed differences in antimicrobial activity levels may have seasonal nature. According to the study by Bankova et al. (1998), the chemical composition of propolis can be influenced by different temperature zones in the regions of propolis collection by bees. Castro et al. (2007) documented the influence of seasonality on antibacterial activity and phenolic composition of propolis in southeastern and northeastern Brazil.

Machado et al. (2016) investigated the antimicrobial activity of the extracts EtOH and SCO2 (propolis samples were donated by the company Apis Nativa Produtos Naturais (Prodapys-Santa Catarina-Brazil), it was noted that all extracts showed activity against gram-positive bacteria Staphylococcus aureus (ATCC 33951 and 25923) and gram-negative Escherichia coli (ATCC 25922), but this effect was dependent on the origin of the matrix and method of extraction. The control sample did not affect the growth of tested bacteria (data not shown). As expected, the extracts from different samples of propolis showed a higher activity against the gram-positive strains than against the gram-negative strains.

Propolis extract showed high percentage of inhibition against tumor lines SF-295, OVCAR-8 and HCT-116. Different results were observed by Silva et al. (2017), who showed that Colon tumor cells (HCT-116) were less sensitive to propolis extracts, with IC50 values ranging from 14.40 to $41.59 \mu \mathrm{g} . \mathrm{mL}^{-1}$. In this same study, R02Et.B2 and R01Et.B2 samples exhibited cytotoxic effects against glioblastoma (SF-295) tumor cell line with $\mathrm{IC}_{50}$ values of $11.22 \pm 16.65 \mu \mathrm{g} . \mathrm{mL}^{-1}$ and $15.10 \pm 22.59 \mu \mathrm{g} . \mathrm{mL}^{-1}$, respectively. Cytotoxic activity of oil extracts of propolis against SF-295 tumors has been described previously by Buriol et al. (2009) and Carvalho et al. (2011). Climate variations might induce changes in the concentration of bioactive compounds of plants, with consequent alterations in the biological activity of the various types of propolis (Isla et al., 2012; Jorge et al., 2008). Although, therapeutic standardisation of propolis is challenging, and the relationship between definite types of propolis and specific biological activities is difficult to establish (Bankova, 2005), the presence of a significant amount of one specific compound might lead to the expectance that the extract has the potential to show bioactivities linked to this potential (Sforcin and Bankova, 2011; Toreti et al., 2013; Mendonça et al., 2015).

Mendonça et al. (2015) demonstrated that, Red propolis collected from Marechal Deodoro city, State of Alagoas, Brazil in concentrations up to $12.5 \mu \mathrm{g} / \mathrm{mL}$, the percentage of viable cells was slightly higher than the negative control. This result might be due to the cytoprotective effects associated with the antioxidant properties of propolis (Kuntz et al., 1999). The cytotoxic activity exhibited a gradual concentration-dependent increase starting at a concentration of $25 \mu \mathrm{g} / \mathrm{mL}$. The number of surviving cells (HCT-116 and OVCAR-8) in the group exposed to EEP at a concentration of $50 \mu \mathrm{g} / \mathrm{mL}$ was similar to those treated with doxorubicin, a drug routinely used for anticancer treatment. These findings are in agreement with the results of the study conducted by Li et al. (2008) using propolis from the same area as in the present study on six different tumour cell lines. In that study, the activity of propolis was similar to that of the investigated anticancer drugs (5-fluorouracil and doxorubicin). An increasing number of epidemiological studies have suggested that flavonoid intake might be associated with a reduced risk of cancer (Wang et al., 2008). This observation has been confirmed in in vitro (Kamei et al., 1996), in vivo (Mulholland et al., 2001) and in clinical studies conducted on humans (Szliszka et al., 2013). 


\section{Conclusion}

The results showed that red propolis Alagoas can be considered as a potential source of substances with antioxidant, antimicrobial and antitumor activity, in addition to non-toxic in the concentrations tested show about $A$. salina. The findings suggest research continuity with the fractions of the crude extract, in order to identify and isolate the active compounds responsible for such activities it is necessary to carry out studies on the bioactive potential of this natural product.

\section{References}

ALVES, E. and KUBOTA, E.H., 2013. Conteúdo de fenólicos, flavonoides totais e atividade antioxidante de amostras de própolis comerciais. Revista Ciências Farmacêuticas Básica e Aplicada, vol. 34, pp. 37-41

AMORIM, A.R., SILVA, M.A., ROCHA, T.J.M., SILVA, A.C.P. and SILVA, E.C.B., 2013. Toxicidade aguda e atividade anti-inflamatória de Hancornia speciosa Gomes (Apocynaceae). Biofar, vol. 9, pp. 164-170.

AQIL, F., AHMAD, I. and MEHMOOD, Z., 2006. Antioxidant and free radical scavenging properties of twelve traditionally used Indian medicinal plants. Turkish Journal of Biology, vol. 30, pp. $177-183$.

AZEVEDO, S.K.S. and SILVA, I.M., 2006. Plantas medicinais e de uso religioso comercializadas em mercados e feiras livres no Rio de Janeiro, RJ, Brasil. Acta Botanica Brasílica, vol. 20, no. 1, pp. 185-194. http://dx.doi.org/10.1590/S0102-33062006000100017.

BANKOVA, V., 2005. Chemical diversity of propolis and the problem of standardisation. Journal of Ethnopharmacology, vol. 100, no. 1-2, pp. 114-117. http://dx.doi.org/10.1016/j. jep.2005.05.004. PMid:15993016.

BANKOVA, V., BOUDOUROVA-KRASTEVA, G., POPOV, S., SFORCIN, J.M. and CUNHA FUNARI, S.R., 1998. Seasonal variations of the chemical composition of Brazilian propolis. Apidologie, vol. 29, no. 4, pp. 361-367. http://dx.doi.org/10.1051/ apido:19980406.

BLANCO-AYALA, T., LUGO-HUITRÓN, R., SERRANOLÓPEZ, E.M., REYES-CHILPA, R., RANGEL-LÓPEZ, E., PINEDA, B., MEDINA-CAMPOS, O.N., SÁNCHEZCHAPUL, L., PINZÓN, E., CRISTINA, T.S., SILVA-ADAYA, D., PEDRAZA-CHAVERRÍ, J., RÍOS, C., DE LA CRUZ, V.P. and TORRES-RAMOS, M., 2013. Antioxidant properties of xanthones from Calophyllum brasiliense: prevention of oxidative damage induced by FeSO. BMC Complementary and Alternative Medicine, vol. 13, pp. 262. PMid:24119308.

BONAMIGO, T., CAMPOS, J.F., ALFREDO, T.M., BALESTIERI, J.B., CARDOSO, C.A., PAREDES-GAMERO, E.J., DE PICOLI SOUZA, K. and SANTOS, E.L., 2017. Antioxidant, cytotoxic, and toxic activities of propolis from two native bees in Brazil: Scaptotrigona depilis and Melipona quadrifasciata anthidioides. Oxidative Medicine and Cellular Longevity, vol. 2017, pp. 1-13. http://dx.doi.org/10.1155/2017/1038153. PMid:28377794.

BURIOL, L., FINGER, D., SCHMIDT, E.M., SANTOS, J.M.T., ROSA, M.R., QUINÁIA, S.P., TORRES, Y.R., DALLA SANTA, H.S., PESSOA, C., MORAES, M.O., COSTA-LOTUFO, L.V., FERREIRA, P.M.P., SAWAYA, A.C.H.F. and EBERLIN, M.N., 2009. Chemical composition and biological activity of oil propolis extract: an alternative to ethanolic extract. Quimica Nova, vol. 32, no. 2, pp. 296-302. http://dx.doi.org/10.1590/ S0100-40422009000200006.

CABRAL, I.S.R., 2008. Isolamento e identificação de compostos com atividade antibacteriana de própolis vermelha brasileira. Piracicaba: Universidade de São Paulo, 94 p. Dissertação de Mestrado em Ciências. http://dx.doi.org/10.11606/D.11.2008. tde-18112008-111056.

CABRAL, I.S.R., OLDONI, T.L.C., PRADO, A., BEZERRA, R.M.N., ALENCAR, S.M., IKEGAKI, M. and ROSALEN, P.L., 2009. Composição fenólica, atividade antibacteriana e antioxidante da própolis vermelha brasileira. Química Nova, vol. 32, no. 6, pp. 1523-1527. http://dx.doi.org/10.1590/S0100-40422009000600031.

CAMPOS, J.F., SANTOS, U.P., MACORINI, L.F.B., MELO, A.M.M.F., BALESTIERI, J.B.P., PAREDES-GAMERO, E.J., CARDOSO, C.A.L., PICOLI SOUZA, K. and SANTOS, E.L., 2014. Antimicrobial, antioxidant and cytotoxic activities of propolis from Melipona orbignyi (Hymenoptera, Apidae). Food and Chemical Toxicology, vol. 65, pp. 374-380. http://dx.doi. org/10.1016/j.fct.2014.01.008. PMid:24412556.

CARVALHO, A.A., FINGER, D., MACHADO, C.S., SCHMIDT, E.M., COSTA, P.M., ALVES, A.P.N.N., MORAIS, T.M.F., QUEIROZ, M.G.R., QUINÁIA, S.P., ROSA, M.R., SANTOS, J.M.T., PESSOA, C., MORAES, M.O., COSTA-LOTUFO, L.V., SAWAYA, A.C.H.F., EBERLIN, M.N. and TORRES, Y.R., 2011. In vivo antitumoural activity and composition of an oil extract of Brazilian propolis. Food Chemistry, vol. 126, no. 3, pp. 1239-1245. http://dx.doi.org/10.1016/j.foodchem.2010.12.035.

CASTRO, M.L., CURY, J.A., ROSALEN, P.L., ALENCAR, S.M., IKEGAKI, M., DUARTE, S. and KOO, H., 2007. Propolis do sudeste e nordeste do Brasil: influência da sazonalidade na atividade antibacteriana e composição fenólica. Química Nova, vol. 30, no. 7, pp. 1512-1516. http://dx.doi.org/10.1590/S010040422007000700003 .

COSTA, P.R.R., 2009. Produtos naturais como ponto de partida para a descoberta de novas substâncias bioativas: Candidatos a fármacos com ação antiofídica, anticâncer e antiparasitária. Revista Virtual de Química, vol. 1, pp. 58-66.

DE-MELO, A.A.M., MATSUDA, A.H., FREITAS, A.S., BARTH, O.M. and ALMEIDA-MURADIAN, L.B., 2014. Capacidade antioxidante da própolis. Pesquisa Agropecuária Tropical, vol. 44, no. 3, pp. 341-348. http://dx.doi.org/10.1590/ S1983-40632014000300004.

ISLA, M.I., DANTUR, Y., SALAS, A., DANERT, C., ZAMPINI, C., ARIAS, M., ORDÓÑEZ, R., MALDONADO, L., BEDASCARRASBURE, E. and NIEVA MORENO, M.I., 2012. Effect of seasonality on chemical composition and antibacterial and anti-candida activities of Argentine propolis. Design of a topical formulation. Natural Product Communications, vol. 7, no. 10, pp. 1315. PMid:23156997.

JORGE, R., FURTADO, N.A.J.C., SOUSA, J.P.B., DA SILVA FILHO, A.A., GREGÓRIO JUNIOR, L.E., MARTINS, C.H.G., SOARES, A.E.E., BASTOS, J.K., CUNHA, W.R. and SILVA, M.L.A., 2008. Brazilian propolis: seasonal variation of the prenylated p-coumaric acids and antimicrobial activity. Pharmaceutical Biology, vol. 46, no. 12, pp. 889-893. http:// dx.doi.org/10.1080/13880200802370373.

KAMEI, H., KOIDE, T., KOJIMAM, T., HASEGAWA, M., TERABE, K., UMEDA, T. and HASHIMOTO, Y., 1996. Flavonoid-mediated tumor growth suppression demonstrated by 
in vivo study. Cancer Biotherapy \& Radiopharmaceuticals, vol. 11, no. 3, pp. 193-196. http://dx.doi.org/10.1089/cbr.1996.11.193. PMid:10851537.

KAMIYA, T., NISHIHARA, H., HARA, H. and ADACHI, T., 2012. Ethanol extract of Brazilian red propolis induces apoptosis in human breast cancer MCF-7 cells through endoplasmic reticulum stress. Journal of Agricultural and Food Chemistry, vol. 60, no. 44, pp. 11065-11070. http://dx.doi.org/10.1021/jf303004n. PMid:23066995.

KUNTZ, S., WENZEL, U. and DANIEL, H., 1999. Comparative analysis of the effects of flavonoids on proliferation, cytotoxicity, and apoptosis in human colon cancer cell lines. European Journal of Nutrition, vol. 38, no. 3, pp. 133-142. http://dx.doi.org/10.1007/ s003940050054. PMid:10443335.

LI, F., AWALE, S., TEZUKA, Y. and KADOTA, S., 2008. Cytotoxic constituents from Brazilian red propolis and their structure-activity relationship. Bioorganic \& Medicinal Chemistry, vol. 16, no. 10, pp. 5434-5440. http://dx.doi.org/10.1016/j. bmc.2008.04.016. PMid:18440233.

MACHADO, B.A., SILVA, R.P., BARRETO, G.D.E.A., COSTA, S.S., SILVA, D.F., BRANDÃO, H.N., ROCHA, J.L., DELLAGOSTIN, O.A., HENRIQUES, J.A., UMSZA-GUEZ, M.A. and PADILHA, F.F., 2016. Chemical Composition and Biological activity of extracts obtained by supercritical extraction and ethanolic extraction of brown, green and red propolis derived from different geographic regions in Brazil. PLoS One, vol. 11, no. 1, pp. e0145954. http://dx.doi.org/10.1371/journal.pone.0145954. PMid:26745799.

MATOS, F.J.A., 1997. Introdução à fitoquímica experimental. 2. ed. Fortaleza: Edições UFC.

MENDONÇA, I.C.G., PORTO, I.C.C.M., NASCIMENTO, T.G., SOUZA, N.S., OLIVEIRA, J.M.S., ARRUDA, R.E.S., MOUSINHO, K.C., SANTOS, A.F., BASÍLIO-JÚNIOR, I.D., PAROLIA, A. and BARRETO, F.S., 2015. Brazilian red propolis: phytochemical screening, antioxidant activity and effect against cancercells. BMC Complementary and Alternative Medicine, vol. 15, no. 1, pp. 2-12. http://dx.doi.org/10.1186/s12906-015-0888-9. PMid:26467757.

MENSOR, L.L., MENEZES, F.S., LEITÃO, G.G., REIS, A.S., SANTOS, T.C., COUBE, C.S. and LEITÃO, S.G., 2001. Screening of Brazilian plant extracts for antioxidant activity by the use of DPPH free radical method. Phytotherapy Research, vol. 15, no. 2, pp. 12-130. http://dx.doi.org/10.1002/ptr.687. PMid:11268111.

MULHOLLAND, P.J., FERRY, D.R., ANDERSON, D., HUSSAIN, S.A., YOUNG, A.M., COOK, J.E., HODGKIN, E., SEYMOUR, L.W. and KERR, D.J., 2001. Pre-clinical and clinical study of QC12, a water-soluble, pro-drug of quercetin. Annals of Oncology : Official Journal of the European Society for Medical Oncology, vol. 12, no. 2, pp. 245-248. http://dx.doi. org/10.1023/A:1008372017097. PMid:11300332.

NINA, N., QUISPE, C., JIMÉNEZ-ASPEE, F., THEODULOZ, C., FERESÍN, G.E., LIMA, B., LEIVA, E. and SCHMEDAHIRSCHMANN, G., 2015. Antibacterial activity, antioxidant effect and chemical composition of propolis from the Región del Maule, Central Chile. Molecules, vol. 20, no. 10, pp. 1-24. http://dx.doi.org/10.3390/molecules201018144. PMid:26457694.

ONDRIAS, K., STASKO, A., HROMADOVÁ, M., SUCHY, V. and NAGY, M., 1997. Pinobanksin inhibits peroxidation of low density lipoprotein and it has electron donor properties reducing alpha-tocopherol radicals. Die Pharmazie, vol. 52, no. 7, pp. 566-567. PMid:9266597.

PINHEIRO, M.S., 2009. Avaliação da atividade antimicrobiana e citoprotetora gástrica dos extratos de mangaba, caju e própolis vermelha. Aracajú: Universidade Federal de Sergipe. Dissertação de Mestrado em Saúde e Ambiente.

RODRIGUES, A.C.F., COSTA, F.F., LIRA, A.L., NASCIMENTO, E.P., SILVA, F.R.G., SOUZA, L.I.O., AZEVEDO, R.R.S., MATOS-ROCHA, T.J. and SANTOS, A.F., 2013. Atividade antibacteriana, antioxidante e toxicidade do extrato etanólico de Senna obtusifolia. Revista Eletrônica de Farmácia, vol. 10, no. 3, pp. 43-53.

SFORCIN, J.M. and BANKOVA, V., 2011. Propolis: is there a potential for the development of new drugs? Journal of Ethnopharmacology, vol. 133, no. 2, pp. 253-260. http://dx.doi. org/10.1016/j.jep.2010.10.032. PMid:20970490.

SILVA, J.C., RODRIGUES, S., FEÁS, X. and ESTEVINHO, L.M., 2012. Antimicrobial activity, phenolic profile and role in the inflammation of propolis. Food and Chemical Toxicology, vol. 50, no. 5, pp. 1790-1795. http://dx.doi.org/10.1016/j.fct.2012.02.097. PMid:22425940.

SILVA, R.P.D., MACHADO, B.A., BARRETO, G.A., COSTA, S.S., ANDRADE, L.N., AMARAL, R.G., CARVALHO, A.A., PADILHA, F.F., BARBOSA, J.D. and UMSZA-GUEZ, M.A., 2017. Antioxidant, antimicrobial, antiparasitic, and cytotoxic properties of various Brazilian propolis extracts. PLoS One, vol. 12, no. 3, pp. 1-18. PMid:28358806.

SOUSA, C.M.M., SILVA, H.R., VIEIRA-JÚNIOR, G.M., AYRES, M.C.C., COSTA, C.L.S. and ARAÚJO, D.S., 2007. Fenólicos totais e atividade antioxidante de cinco plantas medicinais. Química Nova, vol. 30, no. 2, pp. 351-355. http:// dx.doi.org/10.1590/S0100-40422007000200021.

SOUZA, M.T., 2006. Estudo fitoquímico e avaliação da atividade biológica de Matayba elaeagnoides RADLK. Itajaí: Universidade do Vale do Itajaí. Dissertação de Mestrado em Ciências Farmacêuticas.

SZLISZKA, E., SOKÓŁ-ŁĘTOWSKA, A., KUCHARSKA, A.Z., JAWORSKA, D., CZUBA, Z.P. and KRÓL, W., 2013. Ethanolic extract of polish propolis: chemical composition and trail-r2 death receptor targeting apoptotic activity against prostate cancer cells. Evidence-Based Complementary and Alternative Medicine, vol. 2013, pp. 1-12. PMid:24324518.

TORETI, V.C., SATO, H.H., PASTORE, G.M. and PARK, Y.K., 2013. Recent progress of propolis for its biological and chemical compositions and its botanical origin. Evidence-Based Complementary and Alternative Medicine, vol. 2013, pp. 1-13. http://dx.doi.org/10.1155/2013/697390. PMid:23737843.

WANG, T., CHEN, L., WU, W., LONG, Y. and WANG, R., 2008. Potential cytoprotection: antioxidant defence by caffeic acid phenethyl ester against free radical-induced damage of lipids, DNA, and proteins. Canadian Journal of Physiology and Pharmacology, vol. 86, no. 5, pp. 279-287. http://dx.doi. org/10.1139/Y08-029. PMid:18432289.

ZUNINI, M.P., ROJAS, C., DE PAULA, S., ELINGOLD, I., MIGLIARO, E.A., CASANOVA, M.B., et al, 2010. Phenolic contents and antioxidant activity in central-southern Uruguayan propolis extracts. Journal of the Chilean Chemical Society, vol. 55, pp. 141-146. 